\title{
Thrombophilia in pregnancy
}

\author{
Isobel D Walker
}

\begin{abstract}
Thrombophilia can be defined as a predisposition to thrombosis. Abnormalities in haemostasis that are associated with clinical thrombophilia include heritable defects, such as mutations in the genes encoding the natural anticoagulants antithrombin, protein $C$, and protein $S$, or clotting factors prothrombin and factor $\mathrm{V}$, and acquired defects, such as antiphospholipids. Women with thrombophilic defects have been shown to be at increased risk, not only of pregnancy associated thromboembolism, but also of other vascular complications of pregnancy, including pre-eclampsia and fetal loss. Routine thrombophilia screening of all women attending antenatal clinics is not recommended. Because some thrombophilic defects-for example, type 1 antithrombin deficiency and antiphospholipids-are associated with a high risk of recurrent thrombosis or other pregnancy complications, it is suggested that selected women (those with a personal or confirmed family history of venous thromboembolism or with a history of recurrent fetal loss) are screened for these defects to allow pregnancy management planning. (F Clin Pathol 2000;53:573-580)
\end{abstract}

Keywords: thrombophilia; pregnancy

Normal pregnancy is associated with major changes in all aspects of haemostasisincreasing concentrations of most clotting factors, decreasing concentrations of some of the natural anticoagulants, and reducing fibrinolytic activity - so that as pregnancy progresses and during the puerperium the overall balance is shifted towards apparent hypercoagulability. ${ }^{1}$ Hypercoagulability appears to be an important feature in the pathogenesis of many of the complications of pregnancy including venous thromboembolism, pre-eclampsia, intrauterine growth retardation, and fetal loss.

In North America the term thrombophilic has been used to describe individuals who appear to have a predisposition to develop venous thromboembolism. These individuals may have recurrent events, often apparently spontaneously or after trivial provocation and frequently from a young age. In 1990, the British committee for standards in haematology ${ }^{2}$ suggested that the term thrombophilia should be used to describe "the familial or acquired disorders of the haemostatic mechanism which are likely to predispose to (venous) thrombosis". This laboratory based definition is widely used but has several disadvantages. First, it has become evident that many individuals (in fact
Table 1 Thrombophilia defects

\begin{tabular}{ll}
\hline Heritable & Antithrombin deficiency \\
& Protein C deficiency \\
& Protein S deficiency \\
& Factor V Leiden \\
& Prothrombin 20210A \\
& Dysfibrinogenaemia \\
Aquired & Antiphospholipid syndromes \\
Complex & Factor VIII rise \\
& Hyperhomocysteinaemia (?)
\end{tabular}

most) who carry thrombophilic defects remain asymptomatic. Second, although the number of thrombophilic defects has increased since 1990, detailed laboratory investigation still fails to detect any abnormality in at least half of the patients who present with venous thromboembolism, including many who appear clinically thrombophilic.

Thrombophilic defects can be inherited, acquired, or complex - the result of environmental influences, such as diet or other lifestyle factors, interacting with the genetic background. The haemostatic abnormalities currently widely accepted as thrombophilic are listed in table 1.

\section{Heritable thrombophilias}

Currently, a limited number of genetic abnormalities are accepted as independent risk factors for venous thromboembolism. These defects include mutations in the genes encoding the natural anticoagulants antithrombin, protein $\mathrm{C}$, and protein $\mathrm{S}$, which result in a loss of anticoagulant function, and in the genes encoding the clotting factors factor V, prothrombin and rarely fibrinogen, which result in a gain in coagulant function.

ANTITHROMBIN DEFICIENCY

Antithrombin is the primary inhibitor of formed thrombin and of the other activated clotting factors. It is therefore one of the most important physiological regulators of fibrin formation. The rate of inhibition of activated clotting factors by antithrombin is accelerated at least 1000 fold by the binding of heparin (including unfractionated heparin and low molecular weight heparin). Antithrombin activity remains within the normal "non-pregnant" range during uncomplicated pregnancy. ${ }^{1}$ Two major types of antithrombin deficiency are recognised. Type 1 defects are characterised by a quantitative reduction of qualitatively normal protein and type 2 deficiency results from the production of a qualitatively abnormal protein. The risk of venous thromboembolism in patients with antithrombin deficiency is related to the degree of antithrombin activity (the lower the activity the greater the risk of venous thromboembolism); in type 2 deficiency it is related to the mutation site-defects affecting the active (thrombin inhibiting) site are associated with a high risk of 
venous thromboembolism, similar to the risk in type 1 deficiency, and defects at the heparin binding site are associated with a relatively low risk of venous thromboembolism. ${ }^{3}$

Approximately $0.5-1.0 \%$ of non-pregnant patients presenting with venous thromboembolism have been shown to have antithrombin deficiency. ${ }^{45}$ Family studies suggest that antithrombin deficiency is a more severe defect than deficiencies of protein $C$ or protein $S$, with most patients suffering a thrombotic event before the age of 25 years. ${ }^{6-8}$ In a study of 10000 blood donors, the prevalence of type 1 antithrombin defects in the general population was $0.02 \% .^{9}$ This prevalence in the general population compared with the prevalence of $0.5-1.0 \%$ in patients with venous thromboembolism suggests that antithrombin deficiency increases thrombotic risk at least 50 fold in non-pregnant patients.

PROTEIN C DEFICIENCY

Protein C, like its cofactor protein S, is vitamin $\mathrm{K}$ dependent. It circulates in plasma as an inactive precursor. During coagulation, protein $\mathrm{C}$ is activated by thrombin to activated protein C (APC), which with protein $S$ cleaves the activated coagulation cascade cofactors, factor $\mathrm{Va}$ and factor VIIIa, thus limiting the rate of further thrombin production. Protein $\mathrm{C}$ activity remains within the non-pregnant, normal range during uncomplicated pregnancy. ${ }^{1}$ Many mutations resulting in either quantitative or qualitative protein $\mathrm{C}$ defects have been described. In contrast to antithrombin deficiency, where the degree of antithrombin activity and the site of the mutation on the antithrombin gene appear to be useful in predicting the risk of thrombosis, there is no clear correlation between protein $\mathrm{C}$ activity in the plasma or the mutation site and the risk of venous thromboembolism. The prevalence of heterozygous protein $\mathrm{C}$ deficiency in the general population is approximately $0.3 \%{ }^{10}$ and protein C deficiency is reported in around 3\% of unselected patients with a history of venous thromboembolism, ${ }^{411}$ pointing to a relative risk of venous thromboembolism in non-pregnant patients of about 10 .

PROTEIN S DEFICIENCY

In the circulation, $60 \%$ of protein $S$ is bound to $\mathrm{C} 4 \mathrm{~b}$ binding protein, a regulatory protein of the complement pathway, and the remaining $40 \%$ is free. Free protein $\mathrm{S}$ acts as a cofactor for APC in the cleavage of factors Va and VIIIa. The exact mechanism of action of protein $S$ remains incompletely understood, but its importance as an anticoagulant is clearly demonstrated by the association of protein $S$ deficiency with an increased risk of venous thromboembolism. The diagnosis of protein $\mathrm{S}$ deficiency is difficult and fraught with pitfalls. Protein S concentrations are reduced in pregnancy and in women using combined oral contraceptive pills. ${ }^{12}{ }^{13}$ Around 3\% of patients presenting with venous thromboembolism are found to be protein $S$ deficient, ${ }^{11}{ }^{14}$ but the prevalence of protein $S$ deficiency in the general population is unknown. It is therefore not possible to calculate accurately the "size" of the risk of venous thromboembolism associated with protein S deficiency-some authors have suggested it may be as low as twofold, ${ }^{14}$ whereas others have estimated it to be similar to the risk associated with protein C deficiency. ${ }^{15}$

FACTOR V LEIDEN AND ACTIVATED PROTEIN C RESISTANCE

The term APC resistance is used to describe the phenomenon whereby plasma fails to be anticoagulated by the addition of APC in vitro. The phenomenon first attracted attention when it was reported that APC resistance co-segregated with thrombosis in families with familial venous thromboembolism. ${ }^{16}$ Shortly thereafter, it was found that most patients with familial APC resistance have the same point mutation in the gene encoding clotting factor $\mathrm{V} .{ }^{17}$ This mutation, which is widely known as factor $\mathrm{V}$ Leiden, destroys one of the cleavage sites in activated factor $\mathrm{V}$ (factor Va), causing it to be relatively resistant to inactivation by APC. In white populations, heterozygosity for the factor V Leiden mutation is the most common heritable thrombophilic defect. ${ }^{18-20}$ It is found in between $2 \%$ and $15 \%$ of the general population, and is more prevalent in individuals of northern European extraction than in those from southern Europe. In white populations, $20 \%$ of unselected patients with a first venous thromboembolism have been found to have factor V Leiden, ${ }^{19}{ }^{21}$ and in families with familial venous thromboembolism more than half of the probands carry this defect. ${ }^{22}$ Heterozygosity for factor $\mathrm{V}$ Leiden increases the risk of venous thromboembolism in nonpregnant patients three to eightfold, ${ }^{23}$ whereas homozygous individuals have an 80 fold increased risk. ${ }^{19}$

HERITABLE APC RESISTANCE NOT INVOLVING FACTOR V LEIDEN

Rarely, families are found with evidence suggesting familial APC resistance in the absence of factor V Leiden mutation. ${ }^{2425}$ In a very few individuals this is the result of a mutation in an APC cleavage site other than that affected by the factor V Leiden mutation. ${ }^{26}$

PROTHROMBIN G20210A

The most recently described heritable thrombophilic defect is a $\mathrm{G}$ to A transition at nucleotide 20210 in the 3 ' untranslated region of the gene encoding prothrombin. ${ }^{27}$ This polymorphism is associated with increased plasma prothrombin concentrations and an increased risk of venous thromboembolism. The prevalence of this defect in northern Europe is $2 \%$ in healthy populations and around $6 \%$ in unselected non-pregnant patients with a first venous thromboembolism, ${ }^{27}$ but higher prevalences-up to $6.5 \%$ in the general population-are reported from southern Europe, where the prothrombin G20210A mutation might be the most prevalent heritable thrombophilic defect. ${ }^{28}$ The risk of venous thromboembolism in carriers of this defect is 
estimated to be about two to three times that in non-carriers.

COMBINATIONS OF DEFECTS

Heritable thrombophilic defects are much more prevalent than was anticipated originally and it is not at all unusual to find individuals or families with more than one defect. Combinations of deficiencies of natural anticoagulantsantithrombin, protein $\mathrm{C}$, and protein $\mathrm{S}$-are rare because of the low allelic frequencies of each of these defects, but factor V Leiden and the prothrombin G20210A polymorphism are common, and combinations of these defects with each other, with a natural anticoagulant deficiency, or with an acquired or complex thrombophilia are found frequently.

\section{Acquired thrombophilic defects}

ANTIPHOSPHOLIPIDS

The most common and important acquired thrombophilic defects are those broadly grouped together as "antiphospholipids", which comprise lupus inhibitors and raised anticardiolipin antibody concentrations. Antiphospholipids occur in a variety of conditions, including connective tissue disorders (such as systemic lupus erythematosus, systemic sclerosis, and Bechet's syndrome), some infections, exposure to certain drugs (such as phenothiazines, hydralazine, and procainamide), ${ }^{29}$ and sometimes with no evident underlying pathology or drug exposure. ${ }^{30}$ The persisting presence of antiphospholipids (persisting in at least two samples collected at least six weeks apart) is associated with an increased risk of both venous and arterial thrombosis, ${ }^{30} 31$ and has for many years been known to increase the risk of recurrent fetal loss. ${ }^{32}$ Antiphospholipids can be detected by chance in apparently healthy individuals - with no underlying pathology and no history of thrombosis or fetal loss.

The frequency of antiphospholipids in the general population is not well documented but has been estimated to be between $1 \%$ and $2 \% .^{15}{ }^{33}$ The thrombotic risk associated with incidental antiphospholipids positivity appears to be relatively low. ${ }^{34}$ Among patients with venous thromboembolism, the frequency of antiphospholipids is reported to be between $5 \%$ and $15 \% .^{5536}$ It has been estimated that antiphospholipids raise the risk of venous thromboembolism about ninefold, ${ }^{35}$ but the risk of recurrence has been reported to be very high, varying from $22 \%$ to $70 \% .^{37}$

ACQUIRED APC RESISTANCE

Several changes in haemostasis-for example, raised factor VIII concentrations or the presence of antiphospholipids, result in acquired APC resistance. APC resistance increases with increasing age and in women who use oestrogens. ${ }^{38} 39$ APC resistance also increases during normal pregnancy. ${ }^{1}{ }^{40}{ }^{41}$ Increasing APC resistance correlates with venous thromboembolism risk, irrespective of whether or not the patient carries the factor $\mathrm{V}$ Leiden mutation. ${ }^{24} 2542$

\section{Complex thrombophilic defects}

In some patients it is evident that their thrombophilic defect is the result of complex interactions between genetic and environmental factors.

\section{RAISED FACTOR VIII ACTIVITY}

Factor VIII concentrations are in part genetically regulated and partly a response to environmental factors such as stress, oestrogen use, or pregnancy. Raised plasma clotting factor VIII concentrations are a risk factor for venous thromboembolism, with the risk increasing steadily as the concentration of factor VIII increases. In non-pregnant patients, factor VIII concentrations > $>1500 \mathrm{IU} /$ litre are associated with a sixfold increase in the risk of venous thromboembolism compared with patients with factor VIII concentrations $<1000 \mathrm{IU} /$ litre. $^{43}$

\section{HYPERHOMOCYSTEINAEMIA}

Two studies have demonstrated an increased risk of venous thromboembolism associated with mildly raised plasma concentrations of homocysteine. $^{44}$ Hyperhomocysteinaemia may be the result of genetic and acquired conditions. ${ }^{46}$ Classic hyperhomocysteinaemia is uncommon but the $677 \mathrm{C}$ to $\mathrm{T}$ variant in the gene encoding methylene tetrahydrofolate reductase (MTHFR), which leads to the production of a thermolabile variant of the enzyme MTHFR and mildly raised homocysteine concentrations is common. ${ }^{47}$ Environmental causes of hyperhomocysteinaemia include reduced vitamin $\mathrm{B} 6$, vitamin $\mathrm{B} 12$, or folate concentrations. $^{49}$

\section{Pregnancy associated venous \\ thromboembolism}

Venous thromboembolism remains the major cause of maternal mortality and morbidity in the developed world. Estimates of the incidence of pregnancy associated venous thromboembolism vary between one in 1000 and two in 1000 deliveries. ${ }^{50}{ }^{51}$ When compared with a control population in the same age group, ${ }^{52}$ the risk of venous thromboembolism associated with pregnancy appears to be approximately 10 times higher. In a retrospective study of 72201 deliveries in two Glasgow hospitals over an 11 year period, the incidence of objectively confirmed venous thromboembolism was 0.86 / 1000 deliveries. ${ }^{53}$ In this study, the incidence of venous thromboembolism of $0.74 / 1000$ pregnant years is about eight times higher compared with non-pregnant women in this age range, and the venous thromboembolism incidence of 2.50/1000 puerperal years about 25 times higher-highlighting the fact that not only does pregnancy increase the risk of venous thromboembolism but the risk is considerably greater in the puerperium.

\section{Heritable thrombophilia and pregnancy venous thromboembolism}

RISK OF PREGNANCY VENOUS THROMBOEMBOLISM The pathogenesis of venous thromboembolism is complex, but it is becoming increasingly clear that in general it is the supervention of an 
acquired thrombotic risk, such as pregnancy, on an underlying genetic predisposition that precipitates clinical thrombotic events.

Patients with antithrombin deficiency

Early studies suggested that, in the absence of anticoagulant prophylaxis, about $40 \%$ of pregnancies in women with antithrombin deficiency might be complicated by venous thromboembolism..$^{54-56}$ Similar estimates of the incidence of pregnancy associated venous thromboembolism in women with antithrombin deficiency have subsequently been reported by other groups-37\% in an Italian study $^{57}$ and $40 \%$ in a study from Austria, Germany, and Switzerland. ${ }^{58}$ A large proportion of the events in these studies occurred during pregnancy and often early in the first trimester. Because all of these studies were retrospective reports of events occurring in women already known to have antithrombin deficiency, diagnosed because either they personally or other family members had a history of venous thromboembolism, they are biased and the risk of pregnancy associated venous thromboembolism in women with antithrombin deficiency might have been overestimated. In the study of 7221 deliveries in Glasgow reported by McColl et $a l^{53} 50$ of the 62 women with objectively confirmed pregnancy associated venous thromboembolism were followed up. None of these 50 women had previously been investigated for thrombophilia; four were found to have type 1 (quantitative) antithrombin deficiency - suggesting that the risk of developing venous thromboembolism associated with pregnancy is about one in $2.8(36 \%)$ for women with type 1 antithrombin deficiency, which is very similar to the estimates from previously reported studies that found the risk of venous thromboembolism in such women to be approximately 400 fold higher than in the nonpregnant general population. In the Glasgow study, ${ }^{53}$ two other women were found to have type 2 (qualitative) antithrombin defects with reduced antithrombin activity. Both of these women had postpartum events. The risk of pregnancy associated venous thromboembolism for women with type 2 defects seems to be about one in 40 -less than for type 1 defects.

Patients with protein $C$ or protein $S$ deficiency

The incidence of pregnancy associated venous thromboembolism in women with protein $\mathrm{C}$ or protein $\mathrm{S}$ deficiency appears to be considerably less than that for those with antithrombin deficiency. In 1990, Conard and colleagues ${ }^{55}$ reported that the incidence of venous thromboembolism occurring during pregnancy in women with protein $\mathrm{C}$ and protein $\mathrm{S}$ deficiency ( $7 \%$ and $0 \%$, respectively) is significantly lower than the incidence of puerperal events, which was $19 \%$ in protein C deficiency and $17 \%$ in protein $\mathrm{S}$ deficiency. Other workers have confirmed these findings. ${ }^{57}$ Like the early studies of women with antithrombin deficiency, these retrospective studies of women already identified as having protein $\mathrm{C}$ or $\mathrm{S}$ deficiency are subject to bias and possibly overestimate the risk of pregnancy associated venous thromboembolism in women with these defects. In the Glasgow study, ${ }^{53}$ only one patient with protein $\mathrm{C}$ deficiency (with a third trimester venous thromboembolism) was found, suggesting a risk of only one in 113 $(<19 \%)$. No patients with protein S deficiency were found in this study.

\section{Factor V Leiden carriers}

Our own group originally suggested that familial APC resistance might be associated with pregnancy venous thromboembolism. ${ }^{59}$ Studies from Sweden, where the general population prevalence of factor V Leiden is high (10$12 \%)$, reported APC resistance and the factor V Leiden mutation in $46-60 \%$ of patients who had had a pregnancy associated venous thromboembolism..$^{60}{ }^{61}$ Only $8 \%$ of unselected women with pregnancy venous thromboembolism in the Glasgow study ${ }^{53}$ were found to have the factor $\mathrm{V}$ Leiden mutation. In an extension to this study, 87 women with objectively confirmed venous thromboembolism were identified from a total of 93493 deliveries in the two hospitals over a 14 year period, and 75 of these were followed up. ${ }^{62}$ Eight of these 75 were found to carry factor V Leiden-seven heterozygotes (one also heterozygous for prothrombin 20210A) and one homozygotesuggesting a risk of pregnancy venous thromboembolism of less than one in 350 for factor $\mathrm{V}$ Leiden heterozygotes, which is much lower than originally suggested.

\section{Prothrombin G20210A carriers}

There is a paucity of information about the risk of pregnancy venous thromboembolism in carriers of prothrombin G20210A. Only 55 of the women with pregnancy venous thromboembolism in the extended Glasgow study ${ }^{62}$ were tested for the prothrombin G20210A mutation. Four were found to be heterozygous for this defect (one also heterozygous for factor $\mathrm{V}$ Leiden), suggesting a risk of less than one in 300 of pregnancy venous thromboembolism for women with this defect. Most patients with pregnancy associated venous thromboembolism in the Glasgow study found to have factor V Leiden or prothrombin G20210A mutations had additional acquired risk factors for venous thromboembolism.

MANAGEMENT OF PREGNANCY IN WOMEN WITH HERITABLE THROMBOPHILIA

Who should be offered thrombophilia screening?

Heritable thrombophilic defects are prevalent and most carriers remain asymptomatic. Routine screening of all women for thrombophilic defects is not justifiable and may cause more harm than good because finding a defect might precipitate unnecessary intervention with antithrombotics. In Europe, most clinicians recommend screening of women who have a history of venous thromboembolism and many advocate screening of personally asymptomatic women who have a family history of confirmed venous thromboembolism.

Some women with thrombophilia might merit anticoagulant prophylaxis during their pregnancy and all or most who have a personal or 
family history of confirmed venous thromboembolism merit active thromboprohylaxis during the puerperium. Thrombophilia screening of selected women (those with a personal or family history of venous thromboembolism) might provide useful information for the assessment of the individual patient's overall risk of venous thromboembolism and for making decisions about the intensity of anticoagulation treatment and the timing of its introduction.

\section{Choice of anticoagulant}

Because coumarins cross the placenta, they have the potential to cause teratogenicity and fetal bleeding and should be avoided during pregnancy, although they can be used postpartum. ${ }^{63}$ Heparins do not cross the placenta and are safe for the fetus. ${ }^{64}$ Until recently, most experience was with unfractionated heparin. Low molecular weight heparins have logistic advantages over unfractionated heparin and appear to be associated with a lower incidence of heparin induced thrombocytopenia and osteoporosis. In a review of studies in which low molecular weight heparin was used in pregnancy, Sanson et al concluded that they are a safe alternative to unfractionated heparin as an anticoagulant during pregnancy. ${ }^{65}$

Classification of patient venous thromboembolism risk and management protocols

Using the patient's personal past history and the thrombophilia screen result in those women selected for screening, patients may be arbitrarily classified as having a very high, high, or moderate risk of pregnancy associated venous thromboembolism.

Patients with very high risk of venous thromboembolism - Published studies have demonstrated that type 1 and type 2 (reactive site) antithrombin defects are associated with a very high risk of pregnancy associated venous thromboembolism..$^{53}$ Patients who have already been committed to long term anticoagulant prophylaxis should also be considered to be at very high risk during pregnancy. Very high risk patients usually require anticoagulation throughout their entire pregnancy. Patients on longterm coumarin must be counselled about the risk to the fetus of maternal coumarin ingestion during pregnancy, and provision must be made to ensure that coumarin is withdrawn and replaced with heparin no later than 6 weeks gestation. Unfractionated or low molecular weight heparin should be used in doses adjusted to maintain the patient's activated partial thromboplastin time ratio or anti-Xa activity within the therapeutic range throughout the entire pregnancy. ${ }^{6366}$ Prophylactic anticoagulation should be continued for at least six to 12 weeks after delivery.

Patients with high risk of venous thromboembolism - The risk of recurrent venous thromboembolism during pregnancy or the puerperium for a woman with a past history of venous thromboembolism (and not currently using anticoagulants) is not known. The risk is possibly lower for women whose previous event was associated with a transient risk factor than for patients with a persisting thrombotic risk factor (such as thrombophilia) or a history of previous apparently spontaneous venous thromboembolism. ${ }^{63}$

Heterozygous protein $\mathrm{C}$ deficiency seems to be associated with a risk of venous thromboembolism intermediate between that associated with antithrombin deficiency and that associated with factor $\mathrm{V}$ Leiden, prothrombin G20210A, and possibly also heterozygous protein $\mathrm{S}$ deficiency. Combinations of defects or homozygosity for a defect are associated with a higher risk than heterozygosity for an abnormality.

Patients may be considered to be at high risk of pregnancy venous thromboembolism if they have a past history of venous thromboembolism or if they have no personal history of venous thromboembolism but have been screened for thrombophilic defects because they gave a family history of venous thromboembolism and were found to be heterozygous for protein C deficiency, homozygous for factor $\mathrm{V}$ Leiden or the prothrombin G20210A mutation, or to have combinations of defects (other than those involving antithrombin deficiency).

Anticoagulation during pregnancy is indicated for those patients at high risk of pregnancy venous thromboembolism. For such patients it is usually reasonable to use lower prophylactic doses of unfractionated or low molecular weight heparin and to delay introduction of anticoagulant until early to mid second trimester. Prophylactic anticoagulation should be continued for six to 12 weeks postpartum.

Patients at moderate risk of venous thromboembolism - Women who have no personal history of venous thromboembolism but who have been screened for thrombophilic defects because of a family history of venous thromboembolism and been found to be heterozygous for protein S deficiency, factor $\mathrm{V}$ Leiden, or prothrombin G20210A should be considered to be at moderate risk of pregnancy associated venous thromboembolism. However, for these women and their babies the risks associated with antenatal anticoagulation usually outweigh the benefits, and in most of these asymptomatic patients antenatal anticoagulation should be avoided. Like those patients at high and very high risk they should be offered anticoagulant prophylaxis from delivery until at least six weeks postpartum.

Women assessed to be at increased risk of pregnancy associated venous thromboembolism should be encouraged to wear graduated compression stockings throughout their pregnancy and puerperium.

\section{Patients with antiphospholipids}

The incidental finding of antiphospholipids in pregnancy should trigger increased clinical surveillance but pharmacological intervention should be reserved for those women with antiphosphlipids who are symptomatic (for those with a history of venous thromboembolism at very high or high venous thromboembolism risk) and for those with recurrent fetal loss as discussed below. 
Pregnancy loss and pre-eclampsia

Inadequate or abnormal placental vasculature may result in several complications that have potentially serious or even lethal consequences for the mother and her unborn child. These complications include pre-eclampsia, placental abruption, intrauterine growth retardation, miscarriage, and stillbirth. In the general population, spontaneous abortion is not uncommon. About $5 \%$ of women experience two or more consecutive losses and recurrent abortion, defined as three or more consecutive spontaneous pregnancy losses, affects as many as $1-2 \%$ of women of reproductive age. ${ }^{6768}$ Many different abnormalities including fetal chromosomal inversions or translocations, anatomic abnormalities of the maternal uterus, endocrinological abnormalities, and autoimmune disorders can result in recurrent fetal loss, but until recently most events were unexplained.

WOMEN WITH ANTIPHOSPHOLIPIDS

Recurrent fetal loss is a well documented finding in patients with antiphospholipids. ${ }^{69}$ The prevalence of persisting antiphospholipids among women who have a history of recurrent fetal loss is around $15 \% .^{70}$ In these women with persistent antiphospholipids and a history of recurrent fetal loss, the prospective fetal loss rate has been put as high as $90 \% .^{71}$ Antiphospholipid positivity in unselected women is not predictive of poor pregnancy outcome..$^{33}$ About two thirds of women with a history of recurrent pregnancy loss and evidence of antiphospholipids have first trimester losses only; the remaining third suffer both early and late losses or late losses alone. The underlying mechanisms of pregnancy loss in antiphospholipid syndrome are believed to include thrombosis of the placental vasculature, leading to decreased placental perfusion and infarction. ${ }^{72}$

Apart from the risk of venous thromboembolism and the risk of fetal loss, there may be an association between antiphospholipids and other pregnancy complications-for example, severe eclampsia and intrauterine growth retardation.

\section{Management of patients with antiphospholipids} and recurrent fetal loss

Because early pregnancy loss is a common phenomenon screening for antiphospholipids is not recommended after a single event. Screening after three or more consecutive pregnancy losses is the normal recommended practice; however, it is possible that screening for antiphospholipids should be extended to include women who have had two consecutive miscarriages or three or more non-consecutive events. ${ }^{29}$ It might also be worthwhile to screen for antiphospholipids in women with a history of severe pre-eclampsia or severe placental insufficiency. ${ }^{29}$

Few large trials evaluating the management of women with recurrent pregnancy loss and antiphospholipids have been reported. Regimens that have been evaluated include low dose aspirin alone or in combination with heparin. Two randomised trials have demon- strated improved fetal survival with aspirin plus heparin compared with only aspirin. ${ }^{73}{ }^{74}$ Aspirin at $75 \mathrm{mg} /$ day should be commenced as soon as a urine pregnancy test is positive and prophylactic doses of unfractionated or low molecular weight heparin should be introduced as soon as ultrasound confirmation of pregnancy is obtained.

WOMEN WITH HERITABLE THROMBOPHILIA It has been suggested that as many as $65 \%$ of the vascular complications of pregnancy can be accounted for by genetic thrombophilias. ${ }^{75}$ In 1996, Preston et $a{ }^{76}{ }^{76}$ reporting the baseline (recruitment) data for a large European multicentre prospective study of patients with heritable thrombophilias, noted that the rate of fetal loss reported by the 571 women with thrombophilic defects was greater than that reported by the women in the control group. In this study, women with familial thrombophilia, especially those with antithrombin deficiency or with combinations of defects, had an increased risk of fetal loss, particularly late fetal loss. In a case control study of 188 pregnancies in 60 women with thrombophilia, $22 \%$ of the pregnancies in women with heritable defects resulted in fetal loss compared with only $11 \%$ in the 202 pregnancies in the control group. ${ }^{77}$ Several case control studies have suggested a potential relation between factor $\mathrm{V}$ Leiden and the risk of recurrent fetal loss. ${ }^{78-81}$ Other studies have failed to confirm this correlation. ${ }^{82}$

Several reports have suggested an association between APC resistance or factor V Leiden and pre-eclampsia, ${ }^{83}$ and a potential association between factor $\mathrm{V}$ Leiden carriage and HELLP syndrome (haemolysis, elevated liver enzymes, and low platelet count) has been reported. ${ }^{85}$ Recently, Grandone and colleagues $^{81}$ have reported an increased tendency to develop pre-eclampsia in women with factor V Leiden or the C677T mutation in the MTHFR gene, and there is increasing evidence that hyperhomocysteinaemia is associated with vascular placental complications, including placental abruption and intrauterine growth retardation. ${ }^{8687}$ There is early evidence that intervention with antithrombotics might improve pregnancy outcome in women with a history of pre-eclampsia or recurrent pregnancy loss associated with heritable thrombophilia..$^{65} 88$

1 Clark P, Brennand J, Conkie JA, et al. Activated protein C sensitivity, protein $\mathrm{C}$, protein $\mathrm{S}$ and coagulation in normal sensitivity, protein C, protein S and coagulation

2 British Committee for Standards in Haematology (BCSH). Guidelines on the investigation and management of thromGuidelines on the investigation and man
bophilia. F Clin Pathol 1990;43:703-10.

bophilia. I Clin Pathol 1990;43:703-10.
3 Finazzi G, Caccia R, Barbui T. Different prevalence of thromboembolism in the subtypes of congenital antithrombin III deficiency: review of 404 cases [letter]. Thromb Haemost 1987;58:1094.

4 Heijboer H, Brandjes DPM, Buller HR, et al. Deficiencies of coagulation inhibiting and fibrinolytic proteins in outpatients with deep vein thrombosis. N Engl f Med 1990;332: 1512-16.

5 Mateo J, Oliver A, Borrell M, et al. Laboratory evaluation and clinical characterisation of 2132 consecutive unselected patients with venous thromboembolism - results of the Spanish multicentre study on thrombophilia (EMETthe Spanish multicentre study on thrombop

6 Thaler E, Lechner K. Antithrombin III deficiency and thromboembolism. Clin Haematol 1981;10:369-90.

7 Demers C, Ginsberg JS, Hirsh J, et al. Thrombosis in antithrombin III deficient persons: report of a large kindred and literature review. Ann Intern Med 1992;116:754-61. 
8 Hirsh J, Piovella F, Pini M. Congenital antithrombin III deficiency: incidence and clinical features. Am f Med 1989; 87(suppl):34-8.

9 Tait RC, Walker ID, Perry DJ, et al. Prevalence of antithrombin deficiency in the healthy population. $B r f$ Haematol 1994;87:106-12.

10 Tait RC, Walker ID, Reitsma PH, et al. Prevalence of protein $\mathrm{C}$ deficiency in the healthy population. Thromb Haemost 1995;73:87-93.

11 Koster T, Rosendaal FR, Briet E, et al. Protein C deficiency in a controlled series of unselected outpatients: an infrequent but clear risk factor for venous thrombosis, Leiinfrequent but clear risk factor for venous thromb
den thrombophilia study. Blood 1995;85:2756-61.

12 Comp PC, Thurnau GR, Welsh J, et al. Functional and immunologic protein $S$ levels are decreased during pregnancy. Blood 1986;68:881-5.

13 Malm J, Laurell M, Dahlback B. Changes in the plasma levels of vitamin $\mathrm{K}$ dependent protein $\mathrm{C}$ and protein $\mathrm{S}$ and $\mathrm{C} 4 \mathrm{~b}$ binding protein during pregnancy and oral contraception. Br f Haematol 1988;68:437-44.

14 Faioni EM, Valsecchi C, Palla A, et al. Free protein S deficiency is a risk factor for venous thrombosis. Thromb Haemost 1997;78:1343-6.

15 Rosendaal FR. Risk factors for venous thrombotic disease. Thromb Haemost 1999;82:610-19.

16 Dahlback B, Carlsson M, Svensson PJ. Familial thrombophilia due to a previously unrecognised mechanism characterised by poor anticoagulant response to activated protein C. Prediction of a cofactor to activated protein C. Proc Natl Acad Sci U S A 1993;90:1004-8.

17 Bertina RM, Koeleman BPC, Koster T, et al. Mutation in blood coagulation factor $\mathrm{V}$ associated with resistance to activated protein C. Nature 1994;369:64-7.

18 Rees DC, Cox M, Clegg JB. World distribution of FV Leiden. Lancet 1995;346:1133-4.

19 Rosendaal FR, Koster T, Vandenbroucke JP, et al. High risk of thrombosis in patients homozygous for FV Leiden (activated protein C resistance). Blood 1995;85:1504-8.

20 Ridker PM, Miletich JP, Hennekens CH, et al. Ethnic distribution of FV Leiden in $4047 \mathrm{men}$ and women. $7 A M A$ 1997;277:1305-7.

21 Koster T, Rosendaal FR, de Ronde H, et al. Venous thrombosis due to a poor anticoagulant response to activated protein C: Leiden thrombophilia study. Lancet 1993;342: protein $1503-6$.

22 Griffin JH, Evatt B, Wideman C, et al. Anticoagulant protein C pathway defective in a majority of thrombophilic patients. Blood 1993;82:1989-93.

23 Ridker PM, Hennekens CH, Lindpainter K, et al. Mutation in the gene coding for coagulation factor $\mathrm{V}$ and the risk of myocardial infarction, stroke and venous thrombosis in apparently healthy men. $N$ Engl F Med 1995;332:912-17.

24 Zoller B, Svensson PJ, He X, et al. Identification of the same factor $\mathrm{V}$ gene mutation in 47 out of 50 thrombosis prone families with inherited resistance to activated protein C. $\mathcal{F}$ Clin Invest 1994;94:2521-4.

25 Bertina RM, Reitsma PH, Rosendaal FR, et al. Resistance to activated protein C and FV Leiden as risk factors for
venous thrombosis. Thromb Haemost 1995;74:449-53.

26 Williamson $\mathrm{D}$, Brown $\mathrm{K}$, Luddington $\mathrm{R}$, et al. FV Cambridge: a new mutation (Arg306-Thr) associated with the resistance to activated protein C. Blood 1998;91:11404.

27 Poort SR, Rosendaal FR, Reitsma PH, et al. A common genetic variation in the 3 ' untranslated region of the prothrombin gene is associated with elevated plasma prothrombin levels and an increase in venous thrombosis. Blood 1996;88:3698-703.

28 Souto JC, Coll I, Llobe D, et al. The prothrombin 20210A allele is the most prevalent genetic risk factor for venous thromboembolism in the Spanish population. Thromb Haemost 1998;80:306-9.

29 Greaves M, Cohen H, Machin SJ, et al on behalf of the Haemostasis and Thrombosis Task Force of the British Committee for Standards in Haematology. Guidelines on the investigation and management of the antiphospholipid syndrome. Brf Haematol 2000 [In press.]

30 Love PE, Santoro SA. Antiphospholipid antibodies: anticardiolipin and the lupus anticoagulant in systemic lupus erythematosus (SLE) and non SLE disorders. Ann Intern Med 1990;112:682-98.

31 Long AA, Ginsberg JS, Brill-Edwards P, et al. The relationship of antiphospholipid antibodies to thromboembolic disease in systemic lupus erythematosus: a cross sectional study. Thromb Haemost 1991;66:520-4.

32 Ginsberg JS, Brill-Edwads P, Johnston M, et al. Relationship of antiphospholipid antibodies to pregnancy loss in patients
with systemic lupus erythematosus: a cross sectional study. with systemic lupus eryth
Blood 1992;80:975-80.

33 Creagh MD, Duncan SLB, McDonnell JM, et al. Failure of the detection of antiphospholipid antibodies alone to predict poor pregnancy outcome. Br f Haematol 1991;77:4

34 Finazzi G, Brancaccio V, Moia M, et al. Natural history in risk factors for thrombosis in 360 patients with antiphospholipid antibodies: a 4 year prospective study from the Italian registry. Am $\mathcal{F}$ Med 1996;100:530-6.

35 Ginsberg KS, Wells PS, Brill-Edwards P, et al. Antiphospholipid antibodies and venous thromboembolism. Blood 1995;86:3685-91.

36 Simioni P, Prandoni P, Zanon E, et al .Deep venous thrombosis and lupus anticoagulant. Thromb Haemost 1996;76: $187-9$.
37 Khamashta MA, Cuadrado MJ, Mujic F, et al. The management of thrombosis in the antiphospholipid syndrome. $N$ Engl f Med 1995;332:993-7.

38 Olivieri O, Friso S, Manzato F, et al. Resistance to activated protein C in healthy women taking oral contraceptives. $\mathrm{Br}$ f Haematol 1995;91:465-70.

39 Lowe GDO, Rumley A, Woodward M, et al. Activated protein $\mathrm{C}$ resistance and the $\mathrm{FV}: \mathrm{R} 506 \mathrm{Q}$ mutation in a random population sample. Thromb Haemost 1999;81:918-24.

40 Cumming AM, Tait RC, Fildes S, et al. Development of resistance to activated protein

41 Mathonnet F, de Mazancourt P, Bastenaire, et al. Activated rotein $C$ sensitivity ratio in pregnant women at delivery. $B r$ protein C sensitivity ratio in

42 De Visser MCH, Rosendaal FR, Bertina RM, et al. A reduced sensitivity for activated protein $\mathrm{C}$ in the absence of 1999;93:1271-6.

43 Koster T, Blann AD, Briet E, et al. Role of clotting factor VIII in effect of von Willebrand on occurrence of deep vein thrombosis. Lancet 1995:345:152-5.

44 Den Heijer M, Koster T, Blom HJ, et al. Hyperhomocysteinaemia as a risk factor for deep vein thrombosis. $N$ Engl $\mathcal{F}$ Med 1996;334:759-62.

45 Simioni P, Prandoni P, Burlina A, et al. Hyperhomocysteinaemia and deep vein thrombosis.

46 D'Angelo A, Selhub J. Homocysteine and thrombotic disease. Blood 1997;90:1-11.

47 Frosst P, Blom HJ, Milos R, et al. A candidate genetic risk for vascular disease: a common mutation in methylene tetrahydrofolate reductase. Nat Genet 1995;10:111-13.

48 Kang SS, Zhou J, Wong PWK, et al. Intermediate homocysteinaemia: a thermolabile variant of methylene tetrahydrofolate reductase. Am f Hum Genet 1988;48:53645 .

49 Ubbink JB, Vermaac WJ, van der Merwe A, et al. Vitamin B12, vitamin B6 and folate nutritional status in men with hyperhomocysteinaemia. Am f Clin Nutr 1993;57:47-

50 Letsky EA, De Swiet M. Thromboembolism in pregnancy and its management. Br 7 Haematol 1984;57:543-52.

51 Toglia MR, Weg JG. Venous thromboembolism during pregnancy. N Engl F Med 1996;335:108-14.

52 Nordstrom M, Lindblad B, Bergqvist D, et al. A prospective study of the incidence of deep vein thrombosis within a defined urban population. F Intern Med 1992;323: $155-60$

53 McColl MD, Ramsay JE, Tait RC, et al. Risk factors for pregnancy associated venous thromboembolism. Thromb Haemost 1997;78:1183-8.

54 Conard J, Horellou MH, van Dredan P, et al. Pregnancy and congenital deficiency in antithrombin III or protein $C$ [abstract]. Thromb Haemost 1987;58:39.

55 Conard J, Horellou MH, van Dredan P, et al. Thrombosis and pregnancy in congenital deficiencies of antithrombin III, protein S or protein S: study of 78 women. Thromb Haemost 1990;63:319-20.

56 Hellgren M, Tengborn L, Abildgaard U. Pregnancy in women with congenital antithrombin III deficiency. Experience of treatment with heparin and antithrombin. Gynecol Obstet Invest 1992;14:127-41.

57 De Stefano V, Leone G, Masterangelo S, et al. Thrombosis during pregnancy and surgery in patients with congenital deficiency of antithrombin III, protein C-protein S. Thromb Haemost 1994;71:799-800.

58 Pabinger I and Study Group on Natural Inhibitors. Thrombotic risk in hereditary antithrombin III, protein C and protein S deficiency. Arterioscler Thromb Vasc Biol 1996;16: $742-8$.

59 Cook G, Walker ID, McCall F, et al. Familial thrombophilia and activated protein $C$ resistance: a thrombotic risk in pregnancy? Br F Haematol 1987;87:873-5.

60 Hellgren M, Svensson P, Dahlback B. Resistance to activated protein $\mathrm{C}$ is a basis for venous thromboembolism associated with pregnancy and o
Obstet Gynecol 1995;173:210-13.

61 Bokarewa MI, Bremme K, Blomback M. Arg 506-Gln mutation in FV and risk of thrombosis during pregnancy. Br f Haematol 1996;92:473-8.

$62 \mathrm{McColl} \mathrm{MD}$. Venous thrombosis and womens health: identification of risk factors and long term effects. MD Thesis 1999, University of Glasgow, UK

63 Ginsberg JS, Hirsh J. Use of antithrombotic agents during pregnancy. Chest 1998;114:524S-30S.

64 Ginsberg JS, Kowalchuk G, Hirsh J, et al. Heparin therapy during pregnancy: risks to the fetus and mother. Arch Intern 2233-6.

65 Sanson B-J, Lensing AWA, Prins MH, et al. Safety of low molecular weight heparin in pregnancy: a systematic review. Thromb Haemost 1999;81:668-72.

66 Prentice CRM, Samama M, Verhaeghe R, et al. A European view on the North American fifth consensus on antithrombotic therapy. Chest [In press.]

67 Cook CL, Pridham DD. Recurrent pregnancy loss. Curr Opin Obstet Gynecol 1995;7:357-66.

68 Clifford K, Rai R, Watson $\mathrm{H}$, et al. An informative protocol for the investigation of recurrent miscarriage: preliminary experience of 500 consecutive cases. Hum Reprod 1994;9:

69 Triplett DA, Harris EN. Antiphospholipid antibodies and reproduction. Am F Reprod Immunol 1989;21:123-32. 
70 Rai RS, Regan L, Clifford K, et al. Antiphospholipid antibodies and beta 2 glycoprotein 1 in 500 women with recurrent miscarriage: results of a comprehensive screening approach.

71 Rai RS, Cohen H, Clifford K, et al. High prospective fetal loss rate in untreated pregnancies of women with recurrent miscarriage and antiphospholipid antibodies. Hum Reprod 1995;10:3301-4

72 De Wolf F, Carreras LO, Moerman P, et al. Decidual vasculopathy and extensive placental infarction in a patient with repeated thromboembolic accidents, recurrent fetal loss and a lupus anticoagulant. Am 7 Obstet Gynecol 1982;142: 829-34.

73 Rai R, Cohen H, Dave M, et al. Randomised controlled trial of aspirin and aspirin plus heparin in pregnant women with recurrent miscarriage associated with phospholipid antibodies (or antiphospholipid antibodies). BMF 1997;314: $253-7$

74 Kutteh WH. Antiphospholipid antibody associated recurrent pregnancy loss: treatment with heparin and low dose
aspirin is superior to low dose aspirin alone. Am 7 Obstet aspirin is superior to low

75 Kupferminc MJ, Eldor A, Steinman N, et al. Increased frequency of genetic thrombophilias in women with complications of pregnancy. N Engl f Med 1999;340:9-13.

76 Preston FE, Rosendaal FR, Walker ID, et al. Increased fetal loss in women with heritable thrombophilia. Lancet 1996;348:913-16.

77 Sanson BJ, Friederich PW, Simioni P, et al. The risk of abortion and stillbirth in antithrombin, protein $\mathrm{C}$ and protein $\mathrm{S}$ deficient women. Thromb Haemost 1996;75:387-88.

78 Ridker PM, Miletch JP, Buring JE, et al. Factor V Leiden mutation as a risk factor for recurrent pregnancy loss. Ann Intern Med 1998;128:1000-3.
79 Brenner B, Mandel H, Lanir N, et al. Activated protein C resistance can be associated with recurrent fetal loss. $\mathrm{Br} \mathcal{F}$ Haematol 1997;97:51-4.

80 Rotmensch S, Liberati M, Mittlemann M, et al. Activated protein $\mathrm{C}$ resistance and adverse pregnancy outcome. Am $\mathcal{F}$ Obstet Gynecol 1997;177:170-3.

81 Grandone E, Margaglione M, Colaizzo D, et al. Factor V Leiden is associated with repeated and recurrent unexplained fetal losses. Thromb Haemost 1997;77:822-4.

82 Dizon-Townson DS, Kinney S, Branch DW, et al. The factor $\mathrm{V}$ Leiden mutation is not a common cause of recurrent miscarriage. F Reprod Immunol 1997;34:217-23.

83 Dizon-Townson DS, Nelson LM, Easton K, et al. The factor $\mathrm{V}$ Leiden mutation may predispose women to severe pre-eclampsia. Am f Obstet Gynecol 1996;175:902-5.

84 Nagy B, Toth T, Rigo J, et al. Detection of factor V Leiden mutation in severe pre-eclamptic Hungarian women. Clin Genet 1998;53:478-81.

85 Brenner B, Lanir N, Thaler I. HELLP syndrome associated with factor V R506Q mutation. Br f Haematol 1996;92: 999-1001.

86 De Vries JIP, Dekker GA, Huijgens PC, et al. Hyperhomocysteinaemia and protein $\mathrm{S}$ deficiency in complicated pregnancies. Br f Obstet Gynaecol 1997;104:1248-54.

87 Goddijn-Wessel TA, Wouters MG, van der Molen EF, et al. Hyperhomocysteinaemia: a risk factor for placental abruption or infarction. Eur F Obstet Gynecol Reprod Biol 1996;66: 23-9.

88 Preston FE, Rosendaal FR, Walker ID, et al. Thromboprophylaxis in pregnancy reduces fetal losses in women with heritable thrombophilia: a prospective EPCOT study [abstract]. Thromb Haemost 1999;(suppl):227.

\section{Fournal of Clinical Pathology - http://www.jclinpath.com}

Visitors to the world wide web can now access the fournal of Clinical Pathology either through the BMJ Publishing Group's home page (http://www.bmjpg.com) or directly by using its individual URL (http://www.jclinpath.com). There they will find the following:

- Current contents list for the journal

- Contents lists of previous issues

- Members of the editorial board

- Information for subscribers

- Instructions for authors

- Details of reprint services

- Instructions for use of Pathology Interactive.

A hotlink gives access to:

- BMJ Publishing Group home page

- British Medical Association web site

- Online books catalogue

- BMJ Publishing Group books.

The web site is at a preliminary stage and there are plans to develop it into a more sophisticated site. Suggestions from visitors about features they would like to see are welcomed. They can be left via the opening page of the BMJ Publishing Group site or, alternatively, via the journal page, through "about this site". 